\title{
$\mathrm{ZnBr}_{2}$-EMIB-Glycerin 浴からの Zn-Mg 合金電析
}

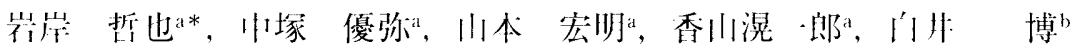 \\ a 姫路工業大学大学院工学研究科（玄671-2201 姫路市書写 2167） \\ b 姫路工業大学上学部（广671-2201 姫路市書写 2167）

\section{Zinc-Magnesium Alloy Electrodeposition from ZnBr2-1-Ethyl-3-Methylimidazolium Bromide Molten Salts with Glycerin}

\author{
Tetsuya IWAGISHI, ${ }^{a *}$ Yuya NAKATSUKA, ${ }^{a}$ Hiroaki YAMAMOTO, ${ }^{a}$ \\ Koichiro KOYAMA, ${ }^{\mathrm{a}}$ and Hiroshi SHIRAI ${ }^{\mathrm{b}}$
}

\begin{abstract}
${ }^{a}$ Graduate School of Engineering, Himeji Institute of Technology (2167, Shosha, Himeji 671-2201, Japan)
${ }^{b}$ Faculty of Engineering, Himeji Institute of Technology (2167, Shosha, Himeji 671-2201, Japan)
\end{abstract}

Received October 6, 2003 ; Accepted May 24, 2004

\begin{abstract}
The electrodeposition of the $\mathrm{Zn}-\mathrm{Mg}$ alloys from Lewis basic $\mathrm{ZnBr}_{2}-\mathrm{MgBr}_{2}$-1-ethyl-3-methylimidazolium bromide (EMIB) molten salts with glycerin, in which $\mathrm{Mg}$ (II) ions were introduced by the chemical reaction of $\mathrm{Mg}$ metal with $\mathrm{Zn}$ (II) ions, was investigated at $140^{\circ} \mathrm{C}$ by potentiostatic and galvanostatic electrolyses and cathodic polarization measurements. The molten salts used were prepared by chemical displacement of prescribed amounts of $\mathrm{Zn}$ in $\mathrm{ZnBr}$-EMIB molten salts with glycerin by $\mathrm{Mg}$. The cathodic polarization curves showed that $\mathrm{EMI}^{+}$cation in the molten salt decomposed below $-1.0 \mathrm{~V}$ vs. $\mathrm{Zn}$ (II) $/ \mathrm{Zn}$ in $\mathrm{ZnBr}$-EMIB-glycerin (15: 42.5: $42.5 \mathrm{~mol} \%$ ). Thus the potentiostatic electrolysis was carried out at $-0.8 \mathrm{~V}$, and the grayish metallic-colored electrodeposits were obtained. The $\mathrm{Mg}$ content in the $\mathrm{Zn}-\mathrm{Mg}$ electrodeposits was from 12 to $25 \mathrm{~mol} \%$. The X-ray diffraction analysis showed the diffraction peaks of $\mathrm{Mg}_{2} \mathrm{Zn}_{11} \mathrm{in}$ addition to $\mathrm{Zn}, \mathrm{CuZn}$, and the substrate $\mathrm{Cu}$, and also suggested the forced dissolution of $\mathrm{Mg}$ in the $\mathrm{Zn}$ matrix. The time of generation of red rust for $\mathrm{Zn}-20 \mathrm{~mol} \% \mathrm{Mg}$ alloy coating steel was about 20 times longer than with that of $\mathrm{Zn}$ coating steel in 5 mass $\% \mathrm{NaCl}$ aqueous solution at $35^{\circ} \mathrm{C}$.
\end{abstract}

Key Words : Zinc-Magnesium Alloy, Electrodeposition, 1-Ethyl-3-methylimidazolium Bromide, Glycerin

\section{1 緒 言}

亜鉛や亜鉛合金めっきは, 防錆めっき法として自動車用外 装材や建材に広く利用されており，水溶液系からの電気めっ き法や溶融めっき法などによって作製されている，近年，実 験室規模ではあるが，鋼板上に真空蒸着法によって作製した Zn-10 mass\%Mg 合金の耐食性について報告されている ${ }^{1}$.

この $\mathrm{Zn}-\mathrm{Mg}$ 合金めっき鋼板の塩水噴霧試験による初期赤錆 発生時間は, 純 $\mathrm{Zn}$ めっき鋼板の約 20 倍であると報告され

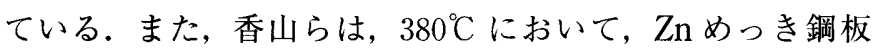

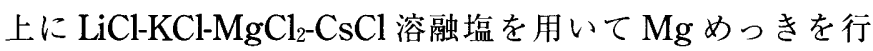
い, $5 \mathrm{mass} \% \mathrm{NaCl}$ 水溶液中で赤錆発生時間を測定した結 果, 赤錆発生時間は基板である $\mathrm{Zn}$ めっき鋼板の約 10 倍で あることを報告している2-4)。これらの結果は, Zn-Mg 合 金めっきは $\mathrm{Zn}$ 単独めっきに比べ，極めて耐食性に優れため つきであることを示している。

水溶液系電解液を用いる電析では，要鉛めっきや $\mathrm{Zn}-\mathrm{Ni}$, Zn-Fe などの亜鉛合金めっきは可能であるが，電極電位の卑 な $\mathrm{Al}$ や $\mathrm{Mg}$ を共析させた $\mathrm{Zn}-\mathrm{Al}$ 合金や $\mathrm{Zn}-\mathrm{Mg}$ 合金の電析 は困難である。このような合金の電析には非水溶液系の電解 (無機系溶融壏, 有機系溶融塩) が有効と考えられる. しか しながら，無機系溶融塩を用いる電気めっきでは，電解温度
が高いため熱処理を施した鋼板の機械的強度を低下させるお それがある. また, 有機溶媒系の電解では, 引火などの点で 取り扱いに問題がある。 そこで著者らは, 非水溶液系の電解 であり，また基板である鋼板の強度を低下させないと考えら れる $150^{\circ} \mathrm{C}$ 以下の温度で操作できる有機系溶融塩を用い, $\mathrm{Zn}-\mathrm{Mg}$ 合金電析を試みることにした.

近年，1-エチル-3-メチルイミダゾリウムクロリド（以下, EMIC と略記) や1-ブチルピリジニウムクロリド（以下, $\mathrm{BPC}$ と略記）などの有機系溶融塩（イオン性液体）を用い た亜鉛および Zn-Ni，Zn-Co 合金の電析が報告されており， さらにこれら有機系溶融塩浴にベンゼンやプロピレンカーボ ネート, エチルアルコール, あるいはプロピルアルコールを 添加すると, カソード電流効率や電析物の表面平滑性が向上 することが報告されている5-13!．著者らは， EMICょりも 吸湿速度が約 2 分の 1 であり，製造コストの安い1-エチル-3メチルイミダゾリウムブロミド（以下，EMIB と略記）を用 いるルイス塩基性 $\mathrm{ZnBr}_{2}-\mathrm{EMIB}$ 浴を用いて $120^{\circ} \mathrm{C}$ で $\mathrm{Zn}$ 電析 を行った。 さらにこの 2 成分浴に 2 価アルコール, 中でもエ チレングリコールを，また， 3 価アルコールのグリセリン (以下, $\mathrm{G}$ と略記) を添加した $\mathrm{ZnBr}_{2}-\mathrm{EMIB}$ 系 3 成分浴を用 いて電解することにより, めっきの光沢性, 平滑性およびカ 
ソード電流効率が向上することを明らかにしている グリセリンを選択したのは，既報18の考察にもとづき， $\mathrm{OH}$ 基の増加が電析物の光沢性, 平滑性の向上に効果があると推 測し，OH 基がエチレングリコールよりもつつ多いこと や，140ㄷ での蒸発が少ないためである.

本研究では，化学置換により $\mathrm{ZnBr}_{2}-\mathrm{EMIB}-\mathrm{G} 3$ 成分浴中 の $\mathrm{Zn} の 一$ 部を $\mathrm{Mg}$ で置き換えた $\mathrm{ZnBr}_{2}$-EMIB-G-Mg（II）

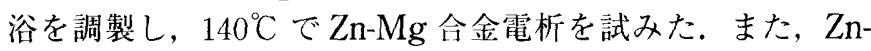
$\mathrm{Mg}$ 合金の電析挙動を電気化学的測定により検討した。得ら れた電析物を X 線回折法, EPMA, ICP 発光分光分析, SEM 観察等によって調べた。

\section{2 実験方法}

\section{1 電解浴の調製}

電解浴には, EMIB (三光化学工業株式会社, $\mathrm{H}_{2} \mathrm{O}: 0.27$ mass \%), $\mathrm{ZnBr}_{2}$ (関東化学株式会社, $\mathrm{H}_{2} \mathrm{O}: 1.1$ mass $\%$ ) およびグリセリン（関東化学株式会社, $\mathrm{H}_{2} \mathrm{O}<30 \mathrm{ppm}$ ）を 用いた。 $\mathrm{EMIB}$ は $80^{\circ} \mathrm{C}, 259.2 \mathrm{ks}$, 減压下（真空度 $1.3 \mathrm{~Pa}$ )

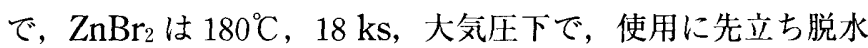
処理を行った。グリセリンは，モレキュラーシーブに浸漬し て脱水処理を行った $\left(\mathrm{H}_{2} \mathrm{O}<10 \mathrm{ppm}\right)$. 脱水した EMIB $\left(\mathrm{H}_{2} \mathrm{O}: 30 \mathrm{ppm}\right)$ と $\mathrm{ZnBr}_{2}\left(\mathrm{H}_{2} \mathrm{O}<10 \mathrm{ppm}\right)$ をガス循環精製 装置（株式会社美和製作所, MS 2-15 S-0）付のアルゴンガ スグローブボックス（株式会社美和製作所，DB 0-1-W）中 で所定のモル比に混合した後， $120^{\circ} \mathrm{C} に$ 加熱し，溶解させた ものを 2 成分浴とした。この 2 成分浴にグリセリンを同様に グローブボックス中で添加し，再び減圧下， $120^{\circ} \mathrm{C} て ゙$ 脱水処 理を行って水分含有量を $10 \mathrm{ppm}$ 末満にしたものを $\mathrm{ZnBr}$ EMIB-G 3 戊分浴として使州した。次に。この3成分浴に全 属 $\mathrm{Mg}$ (粒状，粒径 1 5 mm, 高純度化学株式会社, 99.9\%) を浸漬し，浴中の $\mathrm{Zn}$ イオンの所定量を $\mathrm{Mg}$ イオンで化学置 換させて $\mathrm{ZnBr}_{2}-\mathrm{MgBr}_{2}-\mathrm{EMIB}-\mathrm{G} 4$ 成分浴を調製した。なお， 試薬㧍よび浴中の水分含有量は，上記グローブボックス中で 微量水分測定装置（三菱化学株式会社, CA-100）を用いて, カールフィッシャー法により測定した。 また, 電解浴中の $\mathrm{Zn}$ および $\mathrm{Mg}$ 含有量は, 高周波プラズマ発光分析装置（セ イコー電子株式会社, SPS-4000）を用いて, ICP 発光分光 分析法で測定した.

\section{2 カソード分極曲線}

$\mathrm{ZnBr}_{2}-\mathrm{EMIB}-\mathrm{G}$ 浴からの覀鉛電析および $\mathrm{ZnBr}_{2}-\mathrm{MgBr}_{2}$ EMIB-G 浴からの Zn-Mg 合金電析のカソード分極曲線を測 定した。カソード分極測定は，作用極に前処理として，エメ リー紙（\#1000）による研磨の後，リン酸中で電解研磨を行 った $\mathrm{Cu}$ 板 $(99.99 \%, 10 \mathrm{~mm} \times 30 \mathrm{~mm} \times 0.2 \mathrm{~mm})$, 対極に グラッシーカーボン ( $\phi 6 \mathrm{~mm})$, 参照極には底部をフリッ トガラスで仕切ったパイレックスガラス管 $(\phi 6 \mathrm{~mm})$ 中へ $\mathrm{ZnBr}_{2}$-EMIB-G $(15: 42.5: 42.5 \mathrm{~mol} \%)$ 浴を入れ，これに 99.99\%の亜鉛線を浸漬したものを用い，ポテンショスタッ 卜（北斗電工.株式会社, HSV-100) により走查速度 $0.05 \mathrm{~V}$ $\mathrm{s}^{-1}$ で行った，以後本文中での電位はすべてこの参照電極基 準とする.

\section{3 電解}

電解セルには既報14)に示したものと同様のものを用いた。 カソードには $\mathrm{Cu}$ 板，アノードには $\mathrm{Zn}$ 板，参照極には上述 のものを用いた.いずれの電極も浸漬面積を $200 \mathrm{~mm}^{2}$ とし
た。電解は， $\mathrm{Ar}$ ガス雲囲気で，浴温度 $140^{\circ} \mathrm{C} て ゙ ，-0.8 \mathrm{~V}$ の 定電位電解法（電流密度は $350 \sim 400 \mathrm{~A} \mathrm{~m} \mathrm{~m}^{-2}$ の範囲で変化し た，または電流密度 $300 \mathrm{~A} \mathrm{~m}^{-2}$ の定電流電解法（電位は $-0.8 \sim-1.3 \mathrm{~V}$ の範网で変化した）で行った。電気量は 2.5 $\times 10^{5} \mathrm{C} \mathrm{m} \mathrm{m}^{-2}$ とした。電解後, 電解浴加ら試料を取り出し, 付着した溶融塩を蒸留水，メタノール抢よびアセトンを川い。 て慎重に洗浄して取り除き, 乾燥させた。電析前後のカソー ド電極の質量差を求め, ファラデーの法則により電析に要し た電気量を算出し，それを実際に投入した電気量で除したも のをカソード電流効率とした。

得られた電析物は, X 線回折測定装置（理学電気株式会社, RINT-2200）およびEPMA（株式会社日本電子データム， JXA-8800）を用いて調べた。

\section{4 耐食試験}

酎食試験用試料は，低炭素鋼板 $(10 \times 30 \times 1 \mathrm{~mm})$ を基板 に用いて，電流密度 $300 \mathrm{~A} \mathrm{~m} \mathrm{~m}^{-2}$ で定電流電解による亜鉛め つき，または電位 $-0.8 \mathrm{~V} て ゙$ 定電位電解による $\mathrm{Zn}-\mathrm{Mg}$ 合金 めっきを施すことにより作製した。 めっきされていない部分 はエポキシ樹脂系接着剂（コニシ株式会社）によってマスキ ングした。これらの試料を, 恒温水槽（ヤマト科学株式会社 製，BS-20）で $35^{\circ} \mathrm{C} に$ 設定した 5 mass $\% \mathrm{NaCl}$ 水溶液中 に浸漬し, 試料表面を観察し, 初期赤錆発生時間（試料を浸 漬した後，赤錆が観察されるまでに要した時間）を測定した。

\section{3 実験結果および考察}

\section{1 電解浴の選定}

平滑で金属光沢をもつ $\mathrm{Zn}-\mathrm{Mg}$ 合金めっき膜を高い電流効 率で得るための前実験として，著者らは前報18で $\mathrm{ZnBr}_{2}$ EMIB-G 浴を䏘て 140 CでZn 電析を行った。得られた電 析物の目視観察結果とカソード電流効摔の結果をFig. 1に小 す。この結果から，電流密度 $300 \mathrm{~A} \mathrm{~m}$ ”抢よび $200 \mathrm{~A} \mathrm{~m}$ においても平滑で金属光沢を持ち，100\%のカソード電流效 率で亜鉛電析物が得られる浴組成が分かった（○および○ 印)、また，覀鉛イオン濃度の高い領域では，電流密度 300 A m m $^{-2}$ に拀いてもカソード電流効率は $100 \%$ であが，工

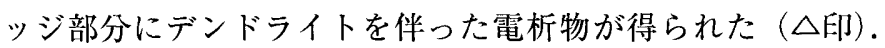
それ以外の浴組成で電解浴が分解し，平滑で金属光沢を持つ

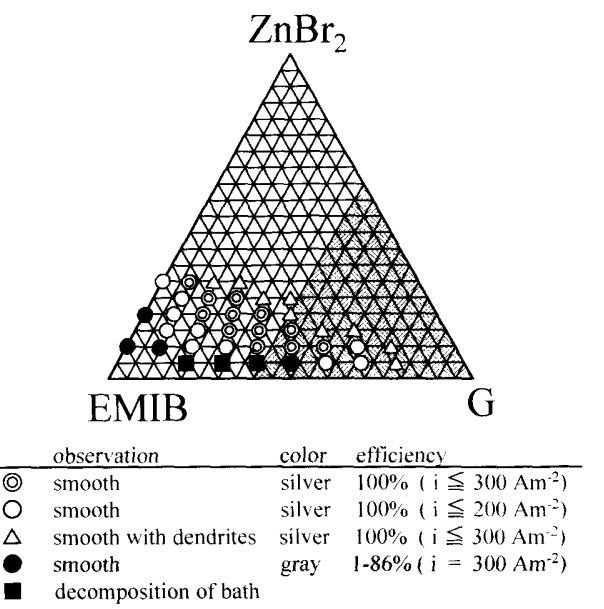

Fig. I Results of visual observation and cathodic current efficiency of electrodeposits from $\mathrm{ZnBr}_{2}-\mathrm{EMIB}$ and $\mathrm{ZnBr}_{2}$-EMIB$\mathrm{G}$ baths at $140^{\circ} \mathrm{C}$. 
電析物が得られず，カソード電流効率は低かった（口印）。 本研究では, Fig. 1 の電解浴に金属 Mg を浸漬し，化学置換 により浴中の $\mathrm{Zn} の \cdots$ 部を $\mathrm{Mg}$ で置き換えて, $\mathrm{Zn}$ と $\mathrm{Mg}$ の 比を変化させて, $\mathrm{ZnBr}_{2}-\mathrm{MgBr}-\mathrm{EMIB}-\mathrm{G} 4$ 成分浴を調製し. 温度 $140^{\circ} \mathrm{C}$, 電流密度 $300 \mathrm{~A} \mathrm{~m}$ 一で定掣流電解を行った。得 られた䉓析物を山視により金禹光汒の有無と平消性について 評価した. Fig. 1 の網掛け以外の領域では化学置換中に電解 浴がゼリー状に変質したり，化学置換ができても電析中にカ ソード電極表面トで黄色の透明な電解浴が茶褐色に変色し, $\mathrm{EMI}^{+}$の還元分解と考えられる反㐫が生じた。したがって， 安定に建浴および電析が可能であった網掛けの部分の領域に ついて詳細に調べた。その中の一例として， $\mathrm{Zn} と \mathrm{Mg}$ の比 を $9: 6,8.5: 6.5,8.4: 6.6$ と し $\mathrm{ZnBr}_{2}-\mathrm{MgBr}_{2}-\mathrm{EMIB}-\mathrm{G}$ 浴から得られた電析物の日視観察結果を Fig. 2 に示す。また， 得られた電析物のカソード電流効率は, 電析物が純 $\mathrm{Zn}$ と仮 定し質量増加より算出した（マグネシウムが共析してくると 電流効率は $100 \%$ よも小さくなる). $\mathrm{Mg}$ 濃度の低い浴 (Fig.2（a)）では，エッジ部分にデンドライトを伴った金属 光沢をもつ電析物が得られ，カソード電流効率は $90 \sim 63 \%$ であった ( $\triangle$ 印).Fig.2（b）抢よび（c）の G 添加量が少 なく, 金属イオン $(\mathrm{Zn}+\mathrm{Mg})$ 濃度の低い浴では, 電析中に カソード電極表面上で黄色の透明な電解浴が茶褐色に変色し, $\mathrm{EMI}^{+}$の還元分解と考えられる反応が生じた（回印）。.例 として, $(\mathrm{Zn}, \mathrm{Mg}) \mathrm{Br}_{2}-\mathrm{EMIB}-\mathrm{G}(5: 38: 57 \mathrm{~mol} \%)$ 浴を 用いて電流密度 $200 \mathrm{~A} \mathrm{~m}$ 2で定電流電解を行った場合の力

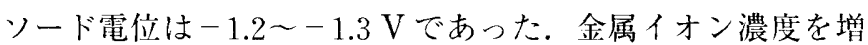
加させると, 平滑で扊色の電析物が得られ, カソード電流効 率は86〜22\%となった（○印）。さらに金属イオン濃度を增

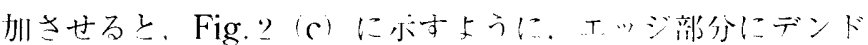
ライトを伴った炎色の電析物( $\mathbf{A}$ 印：カソード電流効㸉 80 〜 $42 \%$ )を経由して，浴分解を起こした（回印：カソード背 流効率 29 0\%). Mgイオン濃度が増加すると電流効率が 低下する理由は，カソード電流効率を質量法で純 Zn の電析 として算出したものであり，Zn-Mg 合金の電析になると $\mathrm{Mg}$ のほが $\mathrm{Zn}$ よりモル質量が小さいため電流効率が 100\%以下と算出されるからである，また，もう一つの理由 は次のように考える. 電析物はFig. 5 のX線回折結果から もわかるように，Zn 抽び $\mathrm{Mg}_{2} \mathrm{Zn}_{11}$ となっていることから， 電解浴中の $\mathrm{Zn}$ イオンの大部分は $\mathrm{Zn}$ として析出し, 残りの $\mathrm{Zn}$ イオンの一部と $\mathrm{Mg}$ イオンの一部が $\mathrm{Mg}_{2} \mathrm{Zn}_{11}$ として析出 することになる。化学置換による $\mathrm{Mg}$ イオンの導入により， 浴中の全金属イオン濃度は変化しないため, 浴の導電率や液

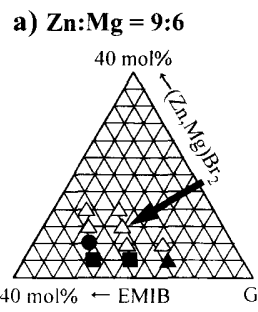

b) $8.5: 6.5$

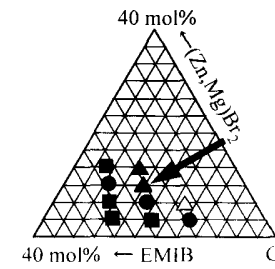

c) 8.4:6.

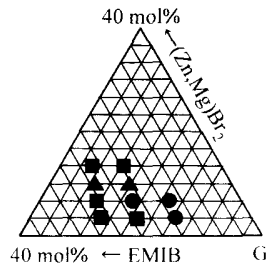

Fig. 2 Results of visual observation of electrodeposits from $\mathrm{ZnBr}_{2}-\mathrm{MgBr}_{2}-\mathrm{EMIB}-\mathrm{G}$ baths at $300 \mathrm{~A} \mathrm{~m}^{-2}$ and $140^{\circ} \mathrm{C} . \triangle$ : Smooth metallic silver colored deposit with dendrites at edges; $\boldsymbol{\Delta}$ : Smooth gray deposit with dendrites at edges; Smooth gray deposit; $\mathbf{a}$ : Decomposition of bath.
抵抗は大きくは変化しないと考えられるが，金属への還元の 段階では， $\mathrm{Mg}$ イオン単独の還元は生じず, $\mathrm{Zn} の$ 析出およ び $\mathrm{Zn}-\mathrm{Mg}$ 合金の誘起共析による $\mathrm{Zn}$ イオンと $\mathrm{Mg}$ イオンの 還元が生じ, 測定した電流効率に相当する印加電流が消費さ れ，残りの印咖電流は， Mgイオンの還えより牛じやすい, $\mathrm{EMI}^{+}$カチオンの還匹に消費される. $\mathrm{Mg}$ イオン濃度が増加 すると電析物中の $\mathrm{Mg}$ 含有量は増加する可能性はあるが, 誘起共析反応の駆動力であるZn イオン濃度が低下するため, 還元電流が流れにくくなり，Zn-Mg 合金電析の電位が卑に 移行し, その分 $\mathrm{EMI}^{+}$カオンの分解が促進され, 結果とし て，電流効率が低下する．Fig.2（a）抢よび（b）の結果か ら, 電流密度 $300 \mathrm{~A} \mathrm{~m}$-2で, エッジ部分にデンドライトを 伴った金属光沢をもつ電析物が得られる浴組成の一つである, (Zn, Mg) Br 2 -EMIB-G (15:25.5 : 59.5 mol\%) 浴を $\mathrm{Zn}-\mathrm{Mg}$ 合金めっきの基本浴として用いることにした（Fig.2（a）お よび (b) の矢印)。すなわち， EMIB と G はそれぞれ 25.5 $\mathrm{mol} \%$ および $59.5 \mathrm{~mol} \%$ と一定にしておいて, $\mathrm{ZnBr}_{2}$ と $\mathrm{MgBr}_{2}$ の $\mathrm{mol}$ 比を変化させた.

\section{2 カソード分極曲線}

$\mathrm{Zn}$ および $\mathrm{Zn}-\mathrm{Mg}$ 合金の析出挙動を検討するため, 温度 $140^{\circ} \mathrm{C}$, 走查速度 $0.05 \mathrm{~V} \mathrm{~s}^{-1}$ で，カソードに $\mathrm{Cu}$ 板を用いて, カソード分極曲線を測定した。電解浴には，(a) $\mathrm{ZnBr}_{2}$ EMIB-G（15:25.5:59.5 mol\%） 3 成分浴および (b) $\mathrm{ZnBr}_{2}-\mathrm{MgBr}_{2}-\mathrm{EMIB}-\mathrm{G}(8.5 ： 6.5: 25.5: 59.5 \mathrm{~mol} \%) 4$ 成分 浴（Fig.2（b）の矢印の組成）を用いた。また，参照のた めに，(c) EMIB 単独浴を用いた。ここで，Znイオンと $\mathrm{Mg}$ イオンの比が $8.5: 6.5$ の電解浴を選択した理由は, 後述 する $\mathrm{Zn}-\mathrm{Mg}$ 合金電析物中の $\mathrm{Mg}$ 命有量老比較すると $\mathrm{Zn}$ : $\mathrm{Mg}=8.5: 6.5$ の浴か门得引机太霄析物のほうが $\mathrm{Mg}$ 在より 多く含有していたためである。その結果を Fig. 3 に乐す. ZnBre-EMIB-G 3 成分浴のカソード分極曲線（(a)）では, 悪鉛の還元析出に対忍して還元電流が, +0.2 V 付近から流 れることが分かった。これに対して， $\mathrm{Mg}$ イオンを導入した $\mathrm{ZnBr}_{2}-\mathrm{MgBr}_{2}-\mathrm{EMIB}-\mathrm{G} 4$ 成分浴の場合 ((b)), +0.2 V 付近 では還元電流は流れず，曹鉛電析浴（a）よりも卑な $0 \mathrm{~V}$ 付 近から還元電流が流れることが分かった。この理由は, 電解 浴（a）の Zn イオンの一部を Mgイオンで置き換えたこと で, Zn 濃度が減少し, その結果還元電流が流れ始める電位 が卑に移行すると考えられる。また， $-1.5 \mathrm{~V}$ 以下の電位で

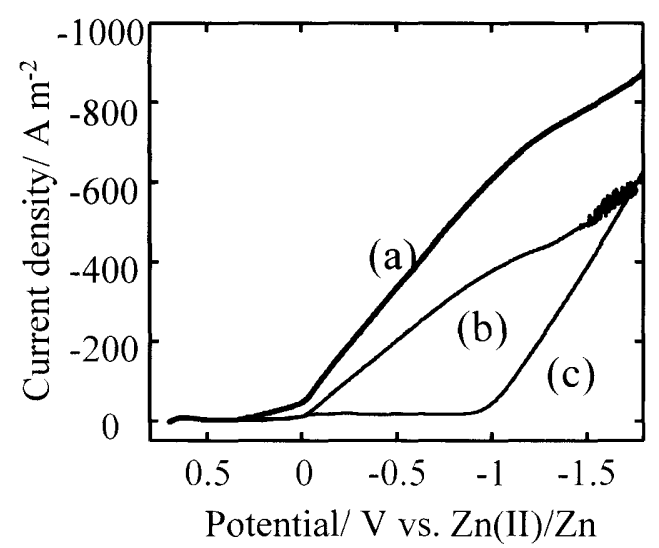

Fig. 3 Polarization curves of $\mathrm{Cu}$ cathode in (a) $\mathrm{ZnBr}_{2}$-EMIBG (15 : $25.5: 59.5 \mathrm{~mol} \%$ ), (b) $\mathrm{ZnBr}_{2}-\mathrm{MgBr}_{2}-\mathrm{EMIB}-\mathrm{G}$ (8.5 : 6.5 : $25.5: 59.5 \mathrm{~mol} \%$ ), (c) $\mathrm{EMIB}$ at $140^{\circ} \mathrm{C}$. 
は，波形の乱れが確認された。これは，EMIB 単独浴でのカ ソード分極曲線 (Fig. 3 (c) ) において, $-1.0 \mathrm{~V}$ 付近から還 元電流が流れ始めること, 電解浴の色がカソード表面で透明 から黄色へと変化することから, $\mathrm{EMI}^{+}$の還元, 军なわち電 解浴の分解によるものと考えられる。

\section{3. $3 \mathrm{Zn-Mg}$ 合金の電析}

Fig. 3 の結果から $\mathrm{ZnBr}_{2}-\mathrm{MgBr}_{2}-\mathrm{EMIB}-\mathrm{G}(8.5 ： 6.5: 25.5$ : $59.5 \mathrm{~mol} \%$ ） 4 成分浴を用いて, 浴の分解電位よりも貴で, かつできるだけ卑な電位一 $0.8 \mathrm{~V} て ゙$ 定電位電解を行った。

Fig. 4 に, 得られた電析物の試料断面の EPMA 分析結果を 示す。これより, 電析物中には, $\mathrm{Zn}$ と $\mathrm{Mg}$ が存在している ことが分かった。また, $\mathrm{Mg}$ は $\mathrm{Zn}$ マトリックスけに均-・に 分散していることが分かった。

次に,この電析物の X 線回折図を Fig. 5 に示す. 比較の ため $\mathrm{ZnBr}_{2}$-EMIB-G (15:25.5:59.5 mol\%) 3 成分浴から 得られた $\mathrm{n}$ 電析物の $\mathrm{X}$ 線回折図も併記した。いずれの $\mathrm{X}$ 線回折図からも $\mathrm{Zn}$ と基板である $\mathrm{Cu}$ のピーク，および $\mathrm{CuZn} \mathrm{n}_{5}$ のピークが確認された. $\mathrm{CuZn} \mathrm{n}_{5}$ は, 既報14で示した ように， $\mathrm{Cu}$ 基板と $\mathrm{Zn}$ 電析物の界面で $\mathrm{Cu}$ と $\mathrm{Zn}$ の相互拡散 によって生成したものと考えられる。一方, $\mathrm{ZnBr}_{2}-\mathrm{MgBr}_{2}$ EMIB-G (8.5:6.5:25.5:59.5 mol\%) 4 成分浴から得られ た電析物の X 線回折図 (Fig. 5 (b)) には, $33^{\circ}(2 \theta)$ と $35^{\circ}$

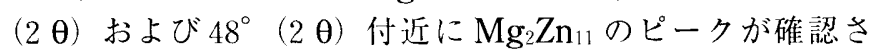
れた。後述する電析物中の $\mathrm{Mg}$ 含有量 $(20 \mathrm{~mol} \%)$ から計

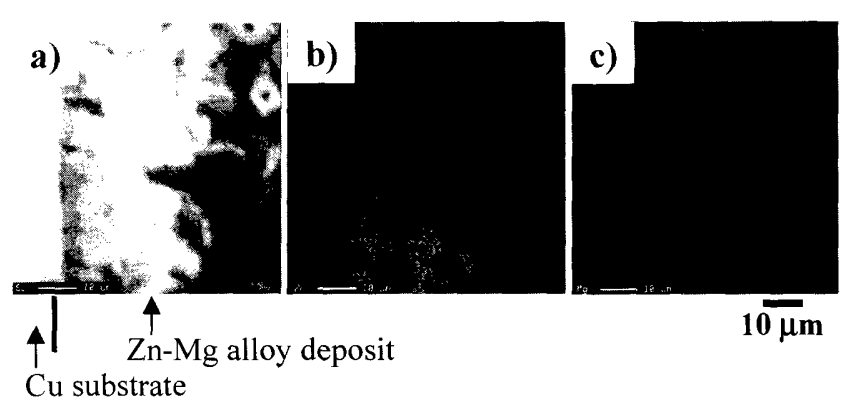

Fig. 4 EPMA photographs of a deposit of $\mathrm{Zn}-\mathrm{Mg}$ alloy at - $0.8 \mathrm{~V}$ from $\mathrm{ZnBr}_{2}-\mathrm{MgBr}_{2}$-EMIB-G (8.5: $6.5: 25.5: 59.5 \mathrm{~mol}$ $\%$ ) molten salt. Charge passed: $2.5 \times 10^{5} \mathrm{C} \mathrm{m}^{-2}$. (a)SEM image, (b) $\mathrm{Zn}-\mathrm{K} \alpha$ image, (c) $\mathrm{Mg}-\mathrm{K} \alpha$ image.

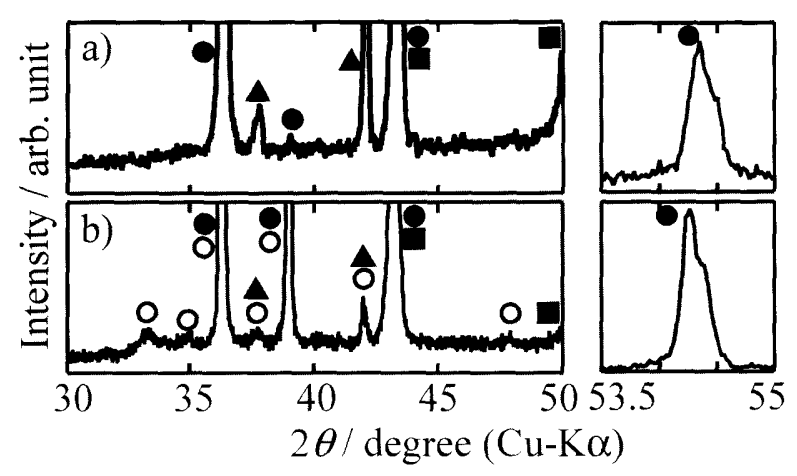

Fig. 5 X-ray diffraction patterns of the specimens obtained from (a) $\mathrm{ZnBr}_{2}$-EMIB-G (10:36:54 mol\%) molten salt at 300 $\mathrm{A} \mathrm{m}{ }^{-2}$ and (b) $\mathrm{ZnBr}_{2}-\mathrm{MgBr}_{2}$-EMIB-G (8.5 : $6.5: 25.5: 59.5$ mol\%) molten salt at $-0.8 \mathrm{~V}$. Charge passed: $2.5 \times 10^{5} \mathrm{C} \mathrm{m}^{-2}$. ○: $\mathrm{Zn}, \mathbf{\square}: \mathrm{Cu}, \boldsymbol{\Delta}: \mathrm{CuZn}_{5}, \bigcirc: \mathrm{Mg}_{2} \mathrm{Zn}_{11}$.
算すると, 電析物中の $\mathrm{Mg}$ は平衡論的には $\mathrm{Mg}_{2} \mathrm{Zn}_{11}$ および $\mathrm{MgZn}_{2}$ の形で存在するはずである19).しかしながら, X 線 回折図には $\mathrm{MgZn}_{2}$ のピークは現れていない. $\mathrm{Zn}-\mathrm{Mg}$ 合金電 析物のX 線回折図の高角度域を詳細に調べたところ，Znの ピークが純要鉛電析物での Zn のピークに比べて，低角度侧 にシフトしていることが明らかとなった。したがって，Mg の一部は Zn に強制固溶されている可能性がある。 そこで, $\mathrm{Zn}$ および $\mathrm{Zn}-\mathrm{Mg}$ 合金電析物 ( $\mathrm{Mg}$ 含有量 $20 \mathrm{~mol} \%$ ) の X 線回折図の高角度域での Zn のピーク [(004), (112), (200)，(201），(104）抢よび（203）を用いて，格子定数 a およびcを算出した。なお，各ピークは高純度 $\mathrm{Si}$ で補正し た.その結果, $Z \mathrm{n}$ 電析物中の $\mathrm{Zn} の$ 格子定数 ( $\AA$ ) は (a, c) $=(2.663 \pm 0.002,4.944 \pm 0.006), \mathrm{Zn}-\mathrm{Mg}$ 合金電析物中 の $\mathrm{Zn}$ の格子定数 $(\AA)$ は $(\mathrm{a}, \mathrm{c})=(2.666 \pm 0.001,4.948$ $\pm 0.007)$ であった.よって，4成分浴から得られた電析物の 格子定数 $\mathrm{a}$ および $\mathrm{c}$ はわずかではあるが増大している傾向が みられた。この $\mathrm{Zn}-\mathrm{Mg}$ 合金電析物は, 電析物の組成からみ て, $\mathrm{MgZn}_{2}$ と $\mathrm{Mg}_{2} \mathrm{Zn}_{11}$ からなるはずである.しかしながら， $\mathrm{X}$ 線回折の結果から, $\mathrm{Zn}$ と $\mathrm{Mg}_{2} \mathrm{Zn}_{11}$ のみが検出された。こ の理由は, $\operatorname{MgZn} \mathrm{n}_{2}$ が非晶質的な結晶で含有されているため と推測する。また，この $\mathrm{Zn}$ は上述したように， $\mathrm{Mg}$ が平衡 状態図以上に固溶した強制固溶体を形成しているものと推測 する。また，電解浴中に水分が存在すると $\mathrm{Mg}$ は $\mathrm{MgO}$ とし て電析物中に析出する可能性がある.しかしながら, X 線回

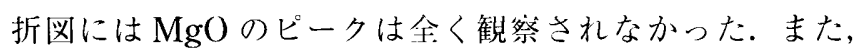
EPMA 分析でも酸素の存在は確認されなかった。この理由 は, 電解浴中の水分含有量が $10 \mathrm{ppm}$ 以卜であったためと考 える.

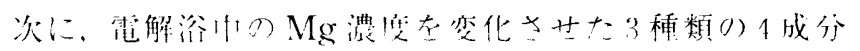
浴を用いて, 埧度 $140^{\circ} \mathrm{C}$, 電位 $-0.8 \mathrm{~V}$ の垚電位電解法で Zn$\mathrm{Mg}$ 電析を行い, 電析物中の $\mathrm{Zn}$ と $\mathrm{Mg}$ の含有望を ICP 発光 分光分析により定量した。その結果をTable 1 に示す。これ より， Mg イオンを $6,6.5$ および $6.6 \mathrm{~mol} \%$ 含有する電解浴 $\left(\mathrm{ZnBr}_{2}-\mathrm{MgBr}_{2}\right.$-EMIB-G (9:6:25.5:59.5 mol\%, 8.5: $6.5: 25.5: 59.5 \mathrm{~mol} \%$ お よ゙ $8.4: 6.6: 25.5: 59.5 \mathrm{~mol} \%)$ ) から得られた $\mathrm{Zn-Mg}$ 合金中には, $\mathrm{Mg}$ がそれぞれ 12, 20, 25 mol\%含有されていることが分かった.さらにこの結果をも とに, 得られた Zn-Mg 合金電析物のカソード電流効率を算 出したところ, いずれの $\mathrm{Zn}-\mathrm{Mg}$ 合金電析物のカソード電流 効率も 100\%であることがわかった。

Fig. 6 に各電解浴から得られた電析物の SEM 観察写真を 示す. 比較のために $\mathrm{ZnBr}_{2}$-EMIB-G 3 成分浴の結果も併記 する. $\mathrm{ZnBr}_{2}$-EMIB-G 3 成分浴からは，平滑で金属光沢をも つ $\mathrm{Zn}$ 電析物が得られ, 平均直径約 $15 \mu \mathrm{m}$ の六角薄板状の結 晶であったが (Fig.6 (a)), $\mathrm{ZnBr}_{2}-\mathrm{MgBr}_{2}-\mathrm{EMIB}-\mathrm{G} 4$ 成分 浴からは，平滑ではあるが，エッジ部分にデンドライトを伴 った金属光沢（死白色）の電析物が得られ，電解浴中の $\mathrm{Mg}$

Table $1 \mathrm{Mg}$ contents in $\mathrm{ZnBr}-\mathrm{MgBr}-\mathrm{EMIB}-\mathrm{G}$ molten salts and deposits.

\begin{tabular}{c|c}
\hline $\mathrm{Mg}(\mathrm{mol} \%)$ in molten salt & $\mathrm{Mg}(\mathrm{mol} \%)$ in deposit \\
\hline 6.0 & 12 \\
\hline 6.5 & 20 \\
\hline 6.6 & 25 \\
\hline
\end{tabular}



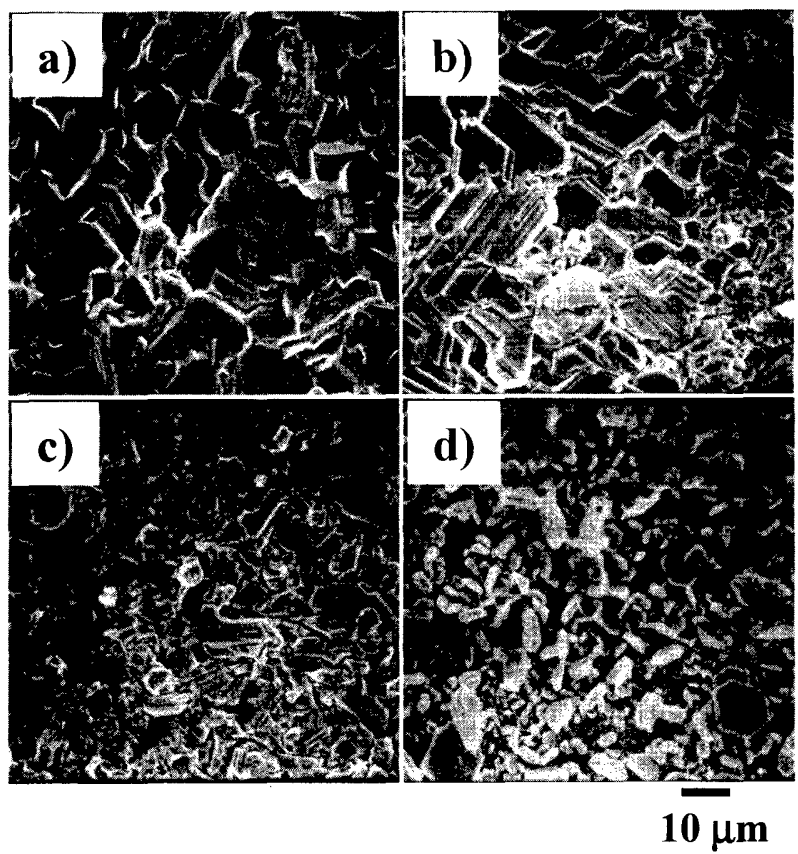

Fig. 6 SEM micrographs of electrodeposits from (a) $\mathrm{ZnBr}_{2}-$ EMIB-G (10: $45: 45 \mathrm{~mol} \%$ ) bath at $300 \mathrm{~A} \mathrm{~m}^{-2}$ and $\mathrm{ZnBr}_{2}$ MgBrz-EMIB-G ((b) $9: 6: 25.5: 59.5 \mathrm{~mol} \%$, (c) $8.5: 6.5: 25.5$ : $59.5 \mathrm{~mol} \%$, (d) $8.4: 6.6: 25.5: 59.5 \mathrm{~mol} \%$ ) baths at $-0.8 \mathrm{~V}$ and $140^{\circ} \mathrm{C}$. Charge passed: $2.5 \times 10^{5} \mathrm{C} \mathrm{m}^{-2}$.

イオン濃度が $6 \mathrm{~mol} \%$ から $6.6 \mathrm{~mol} \%$ へと増加するのに伴い, 結晶は微細になり, 平均直径約 $10 \mu \mathrm{m} の$ 枀角薄板状の結晶 (Fig.6 (b)) から粉状の結晶 (Fig.6 (d)) へと変化するこ 上が分かった。

\section{4 耐食性試験}

$\mathrm{ZnBr}_{2}-\mathrm{EMIB}-\mathrm{G}(15: 42.5: 42.5 \mathrm{~mol} \%) 3$ 成分浴および $\mathrm{ZnBr}_{2}-\mathrm{MgBr}_{2}-\mathrm{EMIB}-\mathrm{G}(8.5: 6.5: 25.5: 59.5 \mathrm{~mol} \%) 4$ 成分

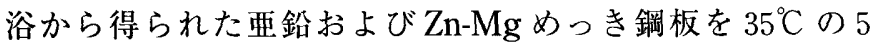
mass\% $\mathrm{NaCl}$ 水溶液に浸漬し, その初期赤錆発生時間を測 定した. 浸漬時間に伴うめっき鋼板の実体写真を Fig. 7 に示 す. 亜鉛めっき鋼板の初期赤錆発生時間は, $439 \mathrm{ks}(122 \mathrm{~h})$ であった. その後, 赤錆は試料全表面へと広がった. 一方, $\mathrm{Zn}-20 \mathrm{~mol} \% \mathrm{Mg}$ めっき鋼板では $8813 \mathrm{ks}$ (2440 h) でも赤 錆を発生しなかった. したがって, Zn-20 mol\% Mgめっき 鋼板の初期赤錆発生時間は覀鉛めっき鋼板に比べて, 約 20 倍以上であることが分かった. Zn-Mgめっき膜が耐食性に 優れている理由は, 現在のところ詳しくは分かっていない. 川福らは，(1)めっき膜の自然電極電位が卑な電位を安定して 維持し，鋼板に対する犠牲防食作用を長時間有すること，(2) $\mathrm{ZnCl}_{2} \cdot 4 \mathrm{Zn}(\mathrm{OH})_{2}$ からなる腐食生成物層がめっき膜表面を 緻密に覆い, 腐食環境下におけるめっき層の溶出を抑制する 保護膜の役割を有すること，の 2 つの作用を上げている ${ }^{1}$. また, 森下らは, $\mathrm{MgO}$ の腐食生成物からなる層がめっき膜 表面を緻密に覆い, 腐食環境下におけるめっき層の溶出を抑 制する保護膜の役割を有することをよげている4!。さらに， 沼倉らは, $\mathrm{Mg}$ 添加は, 亜鉛めっき鋼板の耐食性を低下させ る腐食生成物 $\mathrm{ZnO} の$ 生成を抑制し, より緻密とされる $\mathrm{ZnCl}_{2} \cdot 4 \mathrm{Zn}(\mathrm{OH})_{2}$ の生成を促進するために, 溶存酸素の拡 散が抑えられ，耐食性が向上することを上げている ${ }^{19)}$.

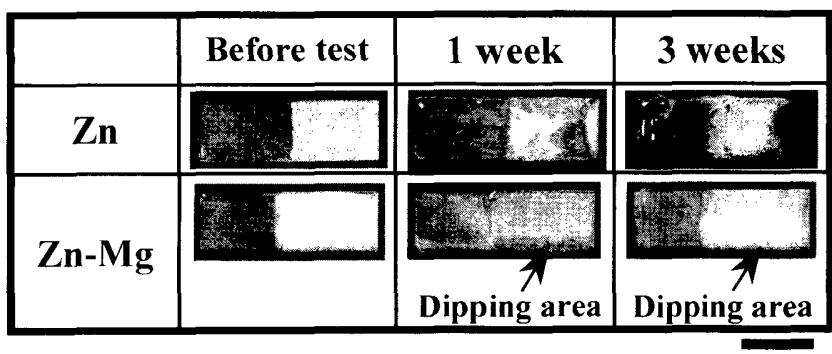

$10 \mathrm{~mm}$

Fig. 7 Appearances of $\mathrm{Zn}$ and $\mathrm{Zn}-20 \mathrm{~mol} \% \mathrm{Mg}$ plated steels after dipping test in 5 mass $\% \mathrm{NaCl}$ aqueous solution at $35^{\circ} \mathrm{C}$.

\section{4 結 言}

ルイス塩基性 $\mathrm{ZnBr}_{2}-\mathrm{EMIB}-\mathrm{G} 3$ 成分浴中の $\mathrm{Zn}$ の一部を化 学置換により $\mathrm{Mg}$ で置き換えた $\mathrm{ZnBr}_{2}-\mathrm{MgBr}_{2}-\mathrm{EMIB}-\mathrm{G} 4$ 成 分浴を用いて, 定電位電解, 定電流電解により $\mathrm{Zn}-\mathrm{Mg}$ 合金 の電析を試みた。さらに, 電析挙動および電析物の特性を力 ソード分極測定, X 線回折, EPMA, ICP 発光分光分析, SEM 観察および耐食試験によって調べ，以下のことを明ら かにした.

（1）カソード分極曲線から-1.5 V ( $\mathrm{Zn}$ (II) $/ \mathrm{Zn}$ in $\mathrm{ZnBr}_{2-}$ EMIB-G $(15: 42.5: 42.5 \mathrm{~mol} \%))$ よりも卑な電位で は，電解浴の分解が激しくなることがわかった。っ て, 電位 $-0.8 \mathrm{~V}$ で定電位電解を行ったところ, 灰色を 帯びた金属色の Zn-Mg 合金電析物が得られた。

(2) $\mathrm{Mg}$ (II) を 6〜6.6 mol\%含有する $\mathrm{ZnBr}_{2}-\mathrm{MgBr}_{2}-\mathrm{EMIB}$ G 4 成分浴を用いて, 電位 $-0.8 \mathrm{~V}$ で定電位電解して得 られためっき膜には，12〜25 $\mathrm{mol} \%$ の $\mathrm{Mg}$ が含有され ていることがわかった。

(3) 電析物の X 線回折測定の結果から, $\mathrm{Mg}$ は $\mathrm{Mg}_{2} \mathrm{Zn}_{11}$ と して，また，一部は $\mathrm{Zn}$ 中に強制湖溶して存在している 可能性が推測される.

（4） $35^{\circ} \mathrm{C}$ の 5 mass \% $\mathrm{NaCl}$ 水溶液に浸漬して初期赤錆発生 時間を測定したところ， $\mathrm{Zn}-20 \mathrm{~mol} \% \mathrm{Mg}$ めっき鋼板は, Znめっき鋼板に比べて約 20 倍の耐食性を示した.

\section{謝 辞}

本研究を遂行するにあたり，試薬を御提供頂きました三光 化学株式会社の小林久文氏に㧍礼申し上げます。また，本研 究の一部は, 平成 14 年度科学研究費補助金（基盤研究 C, 課題番号 14550707）およびマツダ財団助成金によった。

\section{文 献}

1）川福純司, 加藤 淳, 外山雅雄, 池田貢基, 佐藤廣士, 神 戸製鋼技報，43，(No. 3)，19 (1993).

2) M. Morishita, K. Koyama, M. Murase, and Y. Mori, ISIJ International, 36, 714 (1996).

3) M. Morishita, K. Koyama, and Y. Mori, ISIJ International, 37, 55 (1997).

4) M. Morishita, K. Koyama, and Y. Mori, Materials Transactions, JIM, 38, 719 (1997).

5) W. R. Pitner and C. L. Hussey, J. Electrochem. Soc., 144, 3095 (1997).

6) Y.-F. Lin and I. W. Sun, Electrochim. Acta, 44, 2771 (1999).

7) Y.-F. Lin and I. W. Sun, J. Electrochem. Soc., 146, 1054 (1999). 
8）小浦延幸, 満田直樹, 遠藤 巧, 伊藤 滋, 表面技術, 46, 752 (1995).

9）小浦延幸，遠藤 巧，表面技術，46，1191 (1995).

10) N. Koura, T. Endo, and Y. Idemoto, J. Non-Cryst. Solids, 205-207, 650 (1996).

11）鈴小靖庸，松本太，年手本康，小浦延幸，表面技術協会 第 102 回講演大会要旨集, p.177 (2000).

12）小浦延幸, 松本 哲, 井手本康, 表面技術, 49, 1215 (1998).

13）小浦延幸，鈴木靖庸，松本 太，井手本康，表面技術，52， 116 (2001).

14) K. Koyama, T. Iwagishi, H. Yamamoto, H. Shirai, and H. Kobayashi, Electrochemistry, 70, 178 (2002).
15）岩岸哲也, 山本宏明, 香山滉一郎, 白井 博, 小林久文, Electrochemistry, 70, 671 (2002).

16）岩岸哲也, 中塚優弥, 原田 諭, 山本宏明, 香山滉一郎, 白井 博, Electrochemistry, 70, 863 (2002).

17) H. Yamamoto, T. Iwagishi, K. Koyama, H. Shirai, and H. Kobayashi, Proceedings of the 13th International symposium on Molten Salts, MOLTEN SALT XIII, PV 2002-19, p. 863 (2002).

18）岩岸哲也, 白用貴子, 山本宏明, 香山滉一郎, 白井 博, 表面技術，54，76(2003).

19）沼倉行雄，北山実，三吉康彦，日本鉄鋼協会講演要旨集， p. 62(1984). 